\title{
Klebsiella pneumoniae producing extended spectrum $\beta$-lactamase in Regional Military University Hospital of Oran, Algeria: antibiotic resistance, biofilm formation, and detection of blactх-м and blaтем genes
}

\author{
${ }^{* 1}$ Benbrahim, C., ${ }^{1}$ Barka, M. S., ${ }^{2}$ Benmahdi, L., ${ }^{3}$ Zatout, A., and ${ }^{1}$ Khadir, A.
}

\begin{abstract}
${ }^{1}$ Laboratory of Applied Microbiology in Food, Biomedical and Environment (LAMAABE), Department of Biology, Faculty of Nature and Life, Earth and Universal Sciences, Abou Bekr Belkaid University, 13000 Tlemcen, Algeria ${ }^{2}$ Laboratory of Microbiology, Regional Military University Hospital, Oran, Algeria

${ }^{3}$ Laboratory of Microbiology and Plant Biology, Department of Biological Sciences, Faculty of Natural Sciences and Life, University of Abdlhamid Ibn Badis, Mostaganem, Algeria *Correspondence to: chahla.benbrahim@univ-tlemcen.dz
\end{abstract}

\begin{abstract}
:
Background: Klebsiella pneumoniae is a bacterial pathogen commonly associated with severe nosocomial and community acquired infections especially through the acquisition of extended spectrum $\beta$-lactamases (ES $\beta \mathrm{L}$ ) and biofilm formation capacity. The objectives of this study are to determine the prevalence of $K$. pneumoniae $\mathrm{ES} \beta \mathrm{L}$ (KP-ES $\beta \mathrm{L}$ )-producing isolates in the Regional Military University Hospital of Oran (HMRUO) Algeria, characterize their antibiotic resistance profile, genetically detect blaтем and blaстх-м genes, and evaluate their biofilm formation capacity.

Methodology: Different clinical specimens including blood, cerebrospinal fluids, urine and catheter, pus, perirectal abscess, and surgical wounds were collected from patients with suspected clinical infections in different units and departments of the hospital. The specimens were cultured on Blood, MacConkey and CLED agar (for urine only) plates and incubated aerobically for 24 hours at $37^{\circ} \mathrm{C}$ for preliminary identification of bacteria using conventional colony morphology, Gram stain reaction, and disk diffusion test for antibiotic susceptibility testing (AST). Confirmation of isolates, antibiogram, minimum inhibitory concentration (MIC) and detection of resistance phenotypes, were carried out by the automated Vitek 2 (BioMérieux) identification and susceptibility method. ES $\beta$ L production was confirmed by the synergy and combination disk tests. ES $\beta$ L genes were detected by conventional simplex PCR and biofilm formation was detected by the tissue culture plate (TCP) method. Results: A total of 630 patients' clinical samples (one sample per patient) were processed. Klebsiella pneumoniae was isolated in $40(6.3 \%)$ samples, and 15 of these $(37.5 \%)$ produced ES $\beta$ L. In the disk diffusion AST assay, all $40 \mathrm{~K}$. pneumoniae isolates were resistant to ampicillin and ticarcillin while all 40 isolates were sensitive to cefoxitin, imipenem and ertapenem. KP-ESBL producing isolates were more frequently recovered from intensive care unit (33.3\%) and from urine (46.7\%) samples. Group 1 blacтх-м genes were detected in 13 of the $15(86.7 \%) \mathrm{KP}$-ES $\beta$ L isolates, and $46.7 \%$ of these isolates were moderate biofilm producers.

Conclusion: There is need for health departments to put in place preventative measures through regular surveillance of these resistant pathogens and initiating appropriate infection prevention and control strategies to limit their spread in Algerian hospitals and worldwide.
\end{abstract}

Keywords: Klebsiella pneumoniae, ES $\beta$ L, biofilm, PCR, antibacterial resistance

Received May 20, 2020; Revised July 14, 2020; Accepted July 26, 2020

Copyright 2021 AJCEM Open Access. This article is licensed and distributed under the terms of the Creative Commons Attrition 4.0 International License <a rel="license" href="http://creativecommons.org/licenses/by/4.0/", which permits unrestricted use, distribution and reproduction in any medium, provided credit is given to the original author(s) and the source. Editor-in-Chief: Prof. S. S. Taiwo

\section{Klebsiella pneumoniae productrice de-lactamase spectre tendu dans l'hôpital universitaire militaire régional d'Oran, Algérie: résistance aux antibiotiques, formation de biofilm et détection des gènes blactx-m et blateм}

\author{
${ }^{* 1}$ Benbrahim, C., ${ }^{1}$ Barka, M. S., ${ }^{2}$ Benmahdi, L., ${ }^{3}$ Zatout, A., et ${ }^{1}$ Khadir, A.
} ${ }^{* 1}$ Laboratoire de Microbiologie Appliquée à I'Agroalimentaire au Biomédical et à l'Environnement, Département
de Biologie, Facult des sciences de la nature et de la vie de la terre et de l'univers, Université Abou Bekr Belkaid 
Belkaid, 13000 Tlemcen, Algérie

${ }^{2}$ Laboratoire de microbiologie à l'hôpital universitaire militaire régional d'Oran, Algérie

${ }^{3}$ Laboratoire de Microbiologie et Biologie Végétale, Département des Sciences Biologiques, Faculté des Sciences de la Nature et de la Vie, Université Abdlhamid Ibn Badis, Mostaganem, Algérie. *Correspondance à: chahla.benbrahim@univ-tlemcen.dz

\section{Abstrait:}

Contexte: Klebsiella pneumoniae est un pathogène bactérien communément associé aux infections nosocomiales et communautaires sévères, en particulier par l'acquisition de $\beta$-lactamases à spectre étendu $(E S \beta L)$ et la capacité de formation de biofilm. Les objectifs de cette étude sont de déterminer la prévalence des isolats de $K$. pneumoniae producteurs de $\beta$ LSE (KP- $\beta$ LSE) au CHU d'Oran (HMRUO) Algérie, caractériser leur profil de résistance aux antibiotiques, détecter génétiquement les gènes blaтем et blactх-м, et évaluer leur capacité de formation de biofilm.

Méthodologie: Différents échantillons cliniques, y compris du sang, des liquides céphalo-rachidiens, de l'urine mictionnelle et du cathéter, du pus, des abcès périrectal et des plaies chirurgicales ont été prélevés des patients suspectés d'infections cliniques dans différentes unités et départements de l'hôpital. Les échantillons ont été cultivés sur des milieu de culture: deglose au sang, MacConkey et CLED (pour l'urine uniquement) et incubés en aérobie pendant 24 heures à $37^{\circ} \mathrm{C}$ pour l'identification préliminaire des bactéries en utilisant la morphologie conventionnelle des colonies, la coloration de Gram et le test de diffusion sur disque pour les tests de sensibilité aux antibiotiques (AST). La confirmation des isolats, l'antibiogramme, la concentration minimale inhibitrice (CMI) et la détection des phénotypes de résistance ont été réalisés par la méthode automatisée d'identification et de sensibilité sur Vitek 2 (BioMérieux). La production de BLSE a été confirmée par les tests de synergie et de double disques. Les gènes de $\beta L S E$ ont été détectés par PCR simplex conventionnelle et la formation de biofilm a été détectée par la méthode de la plaque de culture tissulaire (TCP).

Résultats: Un total de 630 échantillons cliniques de patients (un échantillon par patient) ont été traités. Klebsiella pneumoniae a été isolé dans 40 échantillons $(6,3 \%)$ et 15 d'entre eux $(37,5 \%)$ ont produit des $\beta$ LSE. Dans le test AST à diffusion sur disque, tous les 40 isolats de $K$. pneumoniae étaient résistants à l'ampicilline et à la ticarcilline, tandis que les 40 isolats étaient sensibles à la céfoxitine, à l'imipénème et à l'ertapénème. Les isolats producteurs de KP-ßLSE ont été plus fréquemment récupérés dans les unités de soins intensifs (33,3\%) et dans les échantillons d'urine (46,7\%). Les gènes blactx-m du groupe 1 ont été détectés dans 13 des 15 isolats de KP- $\beta$ LSE $(86,7 \%)$, et $46,7 \%$ de ces isolats étaient des producteurs de biofilm modérés.

Conclusion: Il est nécessaire que les services de santé mettent en place des mesures préventives grâce à une surveillance régulière de ces pathogènes résistants et à la mise en place de stratégies appropriées de prévention et de contrôle des infections pour limiter leur propagation dans les hôpitaux algériens et dans le monde.

Mots clés: Klebsiella pneumoniae, $\beta \mathrm{LSE}$, biofilm, PCR, résistance antibactérienne

\section{Introduction:}

Bacterial antibiotic resistance (ATB) is constantly evolving. For over 30 years, antibiotic resistance among enterobacteria to the third-generation cephalosporins (3GC) has been steadily increasing, notably through the production of extended-spectrum beta lactamases (ESßLs). These enzymes including TEM, SHV, CTX-M and their derivatives confer resistance on enterobacteria to all $\beta$-lactam agents with exception of cephamycins and carbapenems $(1,2)$. While ES $\beta L$-producing enterobacteria were mostly observed in hospitals with varying isolation frequencies from hospital to hospital, and even from department to department within the same hospital, the diffusion of these multiresistant pathogens into community is of increasing concern. The transmission of genes encoding $\mathrm{ES} \beta \mathrm{L}$, mainly through plasmids, is responsible of their rapid dissemination and thus account for the increased prevalence of ES $\beta L$-producing bacteria worldwide, which constitute a major public health problem $(1,3$,$) .$

Klebsiella pneumoniae is an important opportunistic pathogen causing nosocomial and community associated infections (4). The organism is part of the normal microflora of the intestine and commonly responsible for severe infections of the respiratory tracts (hospital acquired and ventilator associated pneumonia), catheter-related urinary tract infection, meningitis, blood stream infections (bacteremia and septicaemia), infections of surgical and non-surgical wounds, diarrhea, diseases, prosthetic valve endocarditis, peritonitis, and osteomyelitis (5-11).

The first ES $\beta L$-producing $K$. pneumoniae strains were first reported in Europe in 1982 where a new resistance to ceftazidime and aztreonam from plasmid-transmitted $\beta$ lactamase enzyme was quickly and easily disseminated to other Gram-negative bacteria including Escherichia coli. Since the discovery of these enzymes, they have not stopped growing, and today there are over than 200 different ES $\beta L$ enzymes. The impact of the $E S \beta L$ strains is very significant, especially in the intensive care units with a high propensity for epidemic outbreaks. It has been shown in previous European studies that $K$. pneumoniae and $E$. coli were the two most common bacterial species frequently involved in ES $\beta L$ production (12).

There is need for active surveillance 
for ESßL-producing pathogens in high-risk populations using appropriate antimicrobial techniques because these pathogens are generally multiresistant $(12,13)$. ES $\beta L$ genes are typically carried by large transferable plasmids (85-275kb) on which they are often other associated genes coding for resistance to aminoglycosides, chloramphenicol, sulfonamides, trimethoprim, tetracyclines and fluoroquinolones (12). Although, the $\beta$-lactamase inhibitors are used to treat serious infection caused by ES $\beta L$-producing $K$. pneumoniae, this should be done with caution because in vitro sensitivity does not necessarily predict in vivo efficacy (13). Surveys conducted in different countries during specific time periods revealed that once a CTX-M $\beta$-lactamase enters a specific geographic area, it becomes predominant, and displace or superimpose itself over TEM and SHV ES $\beta$ L variants (14).

The main virulence factors contributing to the pathogenesis of $K$. pneumoniae are the capsular polysaccharides and pili type 1 and $3(6,7)$. Biofilms formation is another virulence factor. Biofilms are bacterial populations linked by exopolysaccharide matrices at the surface. This matrix of extracellular polymeric substances (EPS) consists mainly of polysaccharides, proteins, lipids and nucleic acids in varying amounts (11). The first strain of $K$. pneumoniae producing biofilms was described in the late 1988 (7). Biofilmforming bacteria are often observed on the urinary catheter and on the surface of tissues and biomaterials usually at sites of persistent infection, where biofilm formation is a major cause of implant failure, and often limits the lifetime of many permanent medical devices $(7,11)$.

The ability of $K$. pneumoniae to form biofilm provides protection against the host immune system as well as to antibiotics, therefore, biofilms are a major cause of resistance to antimicrobial agents, with resultant high costs of treatment of infections caused by these strains (15). For these reasons, information on ES $\beta L$ and biofilm producing organisms are required for implementtation of preventive procedures and application of infection control measures. The objectives of this study are; to determine the prevalence of $\mathrm{ES} \beta L$-producing $K$. pneumoniae, isolates and their antibiotic resistance profile, genetically detect bla and evaluate their capacity to form biofilms.

\section{Materials and method:}

\section{Study setting and design}

This descriptive cross-sectional study was conducted over a period of 5 months (from October 29, 2017 to March 29, 2018) on 630 patients from different units and departments of the Regional Military University
Hospital of Oran, Algeria, whose clinical samples were collected and processed at the Microbiology Laboratory of the hospital.

\section{Sample and data collection, culture, bacteria isolation and identification}

Clinical specimens comprising voided urine $(n=333)$, pus $(n=173)$, blood for culture $(n=98)$, cerebrospinal fluids $(n=12)$, catheter urine $(n=8)$, perirectal abscess $(n=4)$, and surgical wound $(n=2)$ were collected by standard procedures from patients in different departments/units (paediatrics, infectious disease, general surgery, oncology, pneumology, haematology, intensive care unit, urology, re-education, nephrology, child surgery, and psychiatry) of the hospital, and from some external patients. From each patient, socio-demographic information including age and gender, specimen types, service units, and sampling date, were collected into a designed collection form.

Samples were cultured on Blood and MacConkey agar plates (Fluka), with the exception of urine samples which were cultured on Cysteine Lactose Electrolytes Deficient (CLED) agar medium. All culture plates were incubated aerobically for 24 hours at $37^{\circ} \mathrm{C}$, and bacteria were preliminarily identified by conventional microbiological methods of colony morphology and Gram reactions, and then purified by successive subcultures on MacConkey agar purity plates. Confirmation of $K$. pneumoniae isolates, antibiogram, minimum inhibitory concentrations (MICs) determination and detection of resistance phenotypes were performed with automated VITEK 2 (BioMérieux) ID and susceptibility platform, using GN and AST-N 233 tapes. The susceptibility results were interpreted according to the recommendations of CLSI (16).

\section{Synergy test for ES $\beta L$ production}

Synergy test was performed under the same conditions of the antibiogram after detection of resistance phenotypes by VITEK 2 (BioMérieux) ID. Amoxicillin/clavulanic acid (AMC) disk $(20 / 10 \mu \mathrm{g})$ was placed at $30 \mathrm{~mm}$ center to center of ceftazidime (CAZ) disk $(30 \mu \mathrm{g})$, cefotaxime $(\mathrm{CTX})$ disk $(30 \mu \mathrm{g})$, ceftriaxone (CRO) disk (30 $\mu \mathrm{g})$ and aztreonam (ATM) disk $(30 \mu \mathrm{g})$ on $\mathrm{MH}$ agar plate that has been inoculated with 0.5 McFarland standards suspension of $K$. pneumoniae isolates. Klebsiella pneumoniae ATCC 700603 was used as control. ES $\beta L$ production results in the appearance of an image of synergy or champagne plug (17).

Combination disk test for ES $\beta$ L production The combination disk test was performed by placing clavulanic acid disk (10 $\mathrm{gg})$ and a third generation cephalosporin (3GC) disk at a distance of $30 \mathrm{~mm}$ on a $\mathrm{MH}$ agar 
plate that has been inoculated with 0.5 McFarland standards suspension of $K$. pneumoniae isolates (test), and $K$. pneumoniae ATCC 700603 as control. ES $\beta$ L production was phenotypically confirmed when the inhibition zone diameter of the 3GC disk tower applied after diffusion of the clavulanic acid disk is $\geq 5 \mathrm{~mm}$ in relation to the inhibition zone diameter of the 3GC disk tower (17).

\section{Molecular detection of ES $\beta$ L genes}

Conventional simplex PCR for the detection of blaстX-м and blaTEM genes was performed in the laboratory of Department of Public Health in Naple, Italy, with specific primers (18-20) as shown in Table 1 . The bacterial DNA was extracted by the boiling method (21). PCR was performed in a thermal cycler (Applied Biosystems 2720, California, USA) and the amplification conditions were; initial denaturation at $94^{\circ} \mathrm{C}$ for 5 mins followed by 30 cycles at $94^{\circ} \mathrm{C}$ for 25 seconds, annealing at $52^{\circ} \mathrm{C}$ for 40 seconds, elongation for $72^{\circ} \mathrm{C}$ for 50 seconds and final elongation at $72^{\circ} \mathrm{C}$ for 6 minutes. The PCR products were electrophoresed on $1.5 \%$ agarose gel, visualized in the UV transilluminator after staining with ethidium bromide, and then photographed. The molecular weight marker (100 bp) was used to determine the sizes of the expected bands (Table 1 ).

\section{Biofilm formation by Tissue Culture Plate method (TCP)}

Test for biofilm formation for the $K$. pneumoniae isolates was performed as previously described $(22,23)$ with some modifications. For this purpose, 96-well polystyrene microplates were used. Isolates were grown on nutrient agar for 18-24 hours at $37^{\circ} \mathrm{C}$. One colony of each strain was ino- culated in $5 \mathrm{ml}$ of Brain Heart Infusion Broth (BHIB) and incubated at $37^{\circ} \mathrm{C}$ for 24 hours, then diluted to $1: 100$ in BHIB $+2 \%$ sucrose. Each well in the microplate was filled with $200 \mu \mathrm{L}$ of this dilution (three independent cultures for each species). A sterile broth of BHIB $+2 \%$ sucrose was used as a negative control. The microplates were incubated at $37^{\circ} \mathrm{C}$ for 24 to 48 hours, after which the well contents were gently removed and rinsed four times with TBS ( $\mathrm{pH} \mathrm{7.2)}$ and allowed to dry at $60^{\circ} \mathrm{C}$ for $30 \mathrm{~min}$. Then, the cells adhering to the polystyrene support in the wells were coloured with $200 \mu \mathrm{L}$ of $1 \%$ (w/v) crystal violet for 30 minutes incubation at room temperature. The extra purple crystal violet was poured out and rinse four times at the sterile physiological waters. $200 \mu \mathrm{L}$ of ethanol $95 \%(\mathrm{v} / \mathrm{v})$ was added to each well and left for 15 minutes before reading the optical density (OD) at $550 \mathrm{~nm}$ using a microplate reader (Bio-Rad ELISA, PR 5100).

The interpretation of the results was carried out according to Vuotto et al., (15). The OD of the strains was obtained by the average of the three wells and compared to the OD (mean absorbance) of the negative control (ODC). Non-biofilm producer had OD $\leq O D C$, weak biofilm producer had ODC $\angle O D \leq 2 \times O D C$, moderate biofilm producer had $2 O D C<O D \leq 4 \times O D c$, and strong biofilm producer had $4 \times O D c<O D$.

\section{Statistical analysis}

Data were analysed and presented on Excel sheet as frequency distribution tables and simple graphs. The susceptibility data were analyzed and interpreted using the WHONet 5.6 antibiotic susceptibility surveillance software

Table 1: Primer sequences used for PCR detection of ES $\beta$ L genes

\begin{tabular}{|c|c|c|c|}
\hline Gene & Sequence & Sequences $\left(5^{\prime}--3^{\prime}\right)$ & $\begin{array}{l}\text { Size of the fragments } \\
(\mathrm{pb})\end{array}$ \\
\hline CTX-M group 1 & CTX-M - F & 5'-AAA AAT CAC TGC GCC AGTTC & 415 \\
\hline & CTX-M - R & 5'-AGC TTA TTC ATC GCC ACG TT & \\
\hline CTX-M group 2 & CTX-M - F & 5'-CGA CGC TAC CCC TGC TAT T & 552 \\
\hline CTX-M group 9 & $\begin{array}{l}\text { CTX-M - R } \\
\text { CTX-M - F }\end{array}$ & $\begin{array}{l}\text { 5'-CCA GCG TCA GAT TाT TCA GG } \\
\text { 5'-CAA AGA GAG TGC AACGGA TG }\end{array}$ & 205 \\
\hline CTX-M group 8 & $\begin{array}{l}\text { CTX-M - R } \\
\text { CTX-M - F }\end{array}$ & $\begin{array}{l}\text { 5'-ATT GGA AAG CGT TCA TCA CC } \\
\text { 5'-TCG CGT TAA GCG GAT GAT GC }\end{array}$ & 666 \\
\hline CTX-M group 25 & CTX-M - F & 5'-GCA CGA TGA CAT TCG GG & 327 \\
\hline CTX-M group $8 / 25$ & CTX-M - R & 5'-AAC CCA CGA TGT GGG TAG C & \\
\hline \multirow[t]{2}{*}{ TEM } & TEM - F & 5'-ATG AGT ATT CAA CAT TTC CGT G & 861 \\
\hline & TEM - R & 5'-TTA CCA ATG CTT CAG TGA G AAT & \\
\hline
\end{tabular}




\section{Results:}

During the study period, a total of 630 samples from 630 patients with clinical infections were collected and processed for isolation and identification of bacteria in the laboratory. K. pneumoniae was isolated in 40 $(6.3 \%)$ samples. In the AST assay, all the $K$. pneumoniae isolates were resistant (100\%) to ampicillin and ticarcillin, $10 \%$ to amoxicillin/clavulanic acid, and $2.5 \%$ to piperacillin/tazobactam. On the other hand, $100 \%$ of the isolates were sensitive to cefoxitin, imipenem and ertapenem, while sensitivity to other antibiotics were amikacin $(97.5 \%)$, ofl- oxacin $(87.5 \%)$, ciprofloxacin $(82.5 \%)$, nalidixic acid $(67.5 \%)$, gentamicin $(67.5 \%)$, tobramycin $(65 \%)$, cefotaxime $(62.5 \%)$, ceftazidime $(61.5 \%)$, cephalothin $(60 \%)$, nitrofurantoin $(55 \%)$, and trimethoprim/sulfamethoxazole (50\%) (Fig 1).

The MIC of cefotaxime (CTX) was $\geq$ $64 \mu \mathrm{g} / \mathrm{ml}$, MIC of ceftazidime (CAZ) ranged from $1-\geq 64 \mu \mathrm{g} / \mathrm{ml}$, MIC of cefoxitin (FOX) was in the range of $\leq 4-8 \mu \mathrm{g} / \mathrm{ml}$ and MIC of amoxycillin/clavulanic acid (AMC) was between 16 and $\geq 32 \mu \mathrm{g} / \mathrm{ml}$. Fifteen (15) of the $40(37.5 \%) \mathrm{K}$. pneumoniae isolates were ES $\beta$ L-producing strains (Fig 2a,b) but no carbapenemase producing strain was detected.

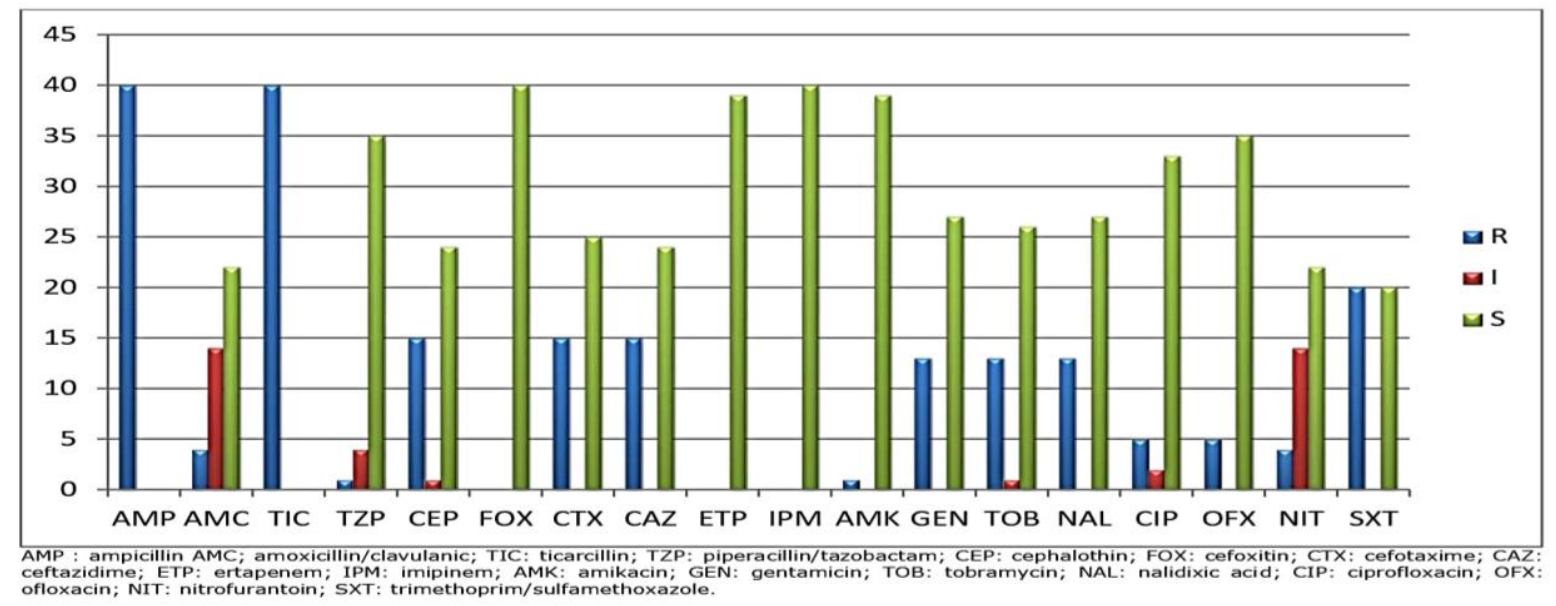

Fig 1: Antimicrobial susceptibility profiles of Klebsiella pneumoniae isolates

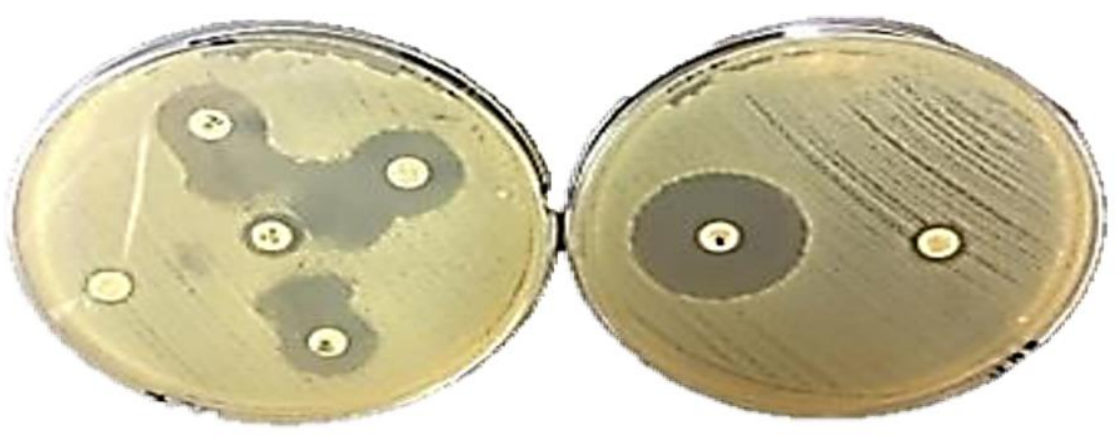

A

Fig 2a: ESßL-producing Klebsiella pneumoniae. A: test positive by synergy; B: test positive by combination disk

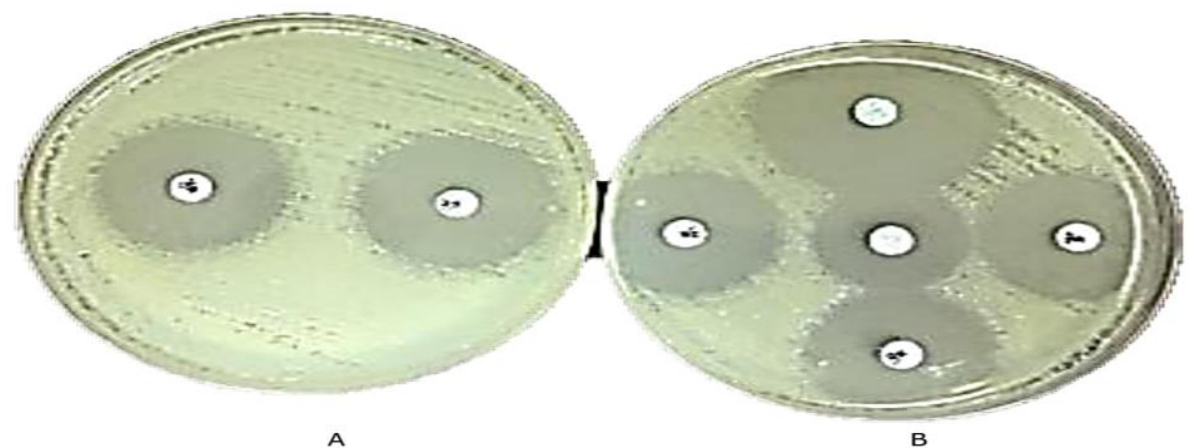

Fig 2b: Non-ESBL-producing Klebsiella pneumoniae. A: test negative by combination disk; B: test negative by synergy 
The ES $\beta$ L-producing isolates were more frequently recovered from urine $(46.7 \%)$, followed by pus, blood culture and perirectal abscess (13.3\% each), and least from surgical wounds and catheters $(6.7 \%$ each). There were no ES $\beta L$-producing strains in the cerebrospinal fluids (Table 2 ).

Table 2: Distribution of Klebsiella pneumoniae and KP-ESBL isolates according to patients' samples

\begin{tabular}{ccc}
\hline Samples & $\begin{array}{c}\text { Number positive for } K \\
\text { pneumoniae }(\%)\end{array}$ & $\begin{array}{c}\text { No positive for ES } \beta \text { L } \\
(\%)\end{array}$ \\
\hline Surgical wound ( $n=2)$ & $1(2.5)$ & $1(6.7)$ \\
Perirectal abscess ( $n=4)$ & $2(5.0)$ & $2(13.3)$ \\
Catheter urine ( $n=8)$ & $2(5.0)$ & $1(6.7)$ \\
Cerebrospinal fluid ( $n=12)$ & $2(5.0)$ & 0 \\
Blood ( $n=98)$ & $2(5.0)$ & $2(13.3)$ \\
Pus ( $n=173)$ & $11(27.5)$ & $2(13.3)$ \\
Urine $(n=333)$ & $20(50.0)$ & $7(46.7)$ \\
Total $(n=630)$ & 40 & $15(37.5)$ \\
\hline
\end{tabular}

Twenty-seven $K$. pneumoniae isolates (65.7\%) were recovered from male patients, $13(48.2 \%)$ of which were ES $\beta$ L producers, while 13 isolates $(32.5 \%)$ were recovered from female patients, 2 (15.4\%) of which were ES $\beta L$ producers. The age group distribution of the patients with KP-ESBL-producing isolates shows that 3 patients $(20 \%)$ were in the age group 21-30 years, while 2 patients $(13.3 \%)$ each were in age groups $<10$ years, $10-20$ years, $31-40$ years, $41-50$ years, $51-60$ years and $>60$ years. Most $\mathrm{ES} \beta \mathrm{L}$-producing strains were isolated in the intensive care unit $(33.3 \%, n=5)$, followed by general surgery $(20 \%, \mathrm{n}=3)$, paediatrics and urology units $(13.3 \%, n=2)$ each, and $6.7 \%$ $(n=1)$ each from nephrology, re-education and psychiatry units (Table 3 ).

\begin{tabular}{ccc} 
Table 3: Distribution of Klebsiella pneumoniae and KP-ESBL isolates by departments/units of patients \\
\hline Service & $\begin{array}{c}\text { Number of } K \text {. } \\
\text { pneumoniae isolates }\end{array}$ & No positive for ES $\beta L$ (\%) \\
\hline Paediatrics & 3 & $2(13.3)$ \\
Infectious disease & 6 & 0 \\
General surgery & 6 & $3(20)$ \\
Oncology & 1 & 0 \\
Pneumology & 3 & 0 \\
Haematology & 1 & 0 \\
Intensive care unit & 8 & $5(33.3)$ \\
Urology & 5 & $2(13.3)$ \\
Re-education & 1 & $1(6.7)$ \\
Nephrology & 4 & $1(6.7)$ \\
Child surgery & 1 & 0 \\
Psychiatry & 1 & $1(6.7)$ \\
Total & 40 & $15(37.5)$
\end{tabular}

Group 1 bla PCR from $13(86.7 \%)$ of the $15 \mathrm{KP}-\mathrm{ES} \beta \mathrm{L}$ producing isolates, while $2(13.3 \%)$ isolates did not contain the gene (Fig 3a). No blaтем gene was detected in any of the isolates (Fig 3b). The results of the biofilm formation with TCP test for KP-ES $\beta \mathrm{L}$ producing isolates showed that $7(46.7 \%)$ were moderate, $7(46.7 \%)$ were weak biofilm producers, while $1(6.7 \%)$ was non biofilm producer (Fig 4).

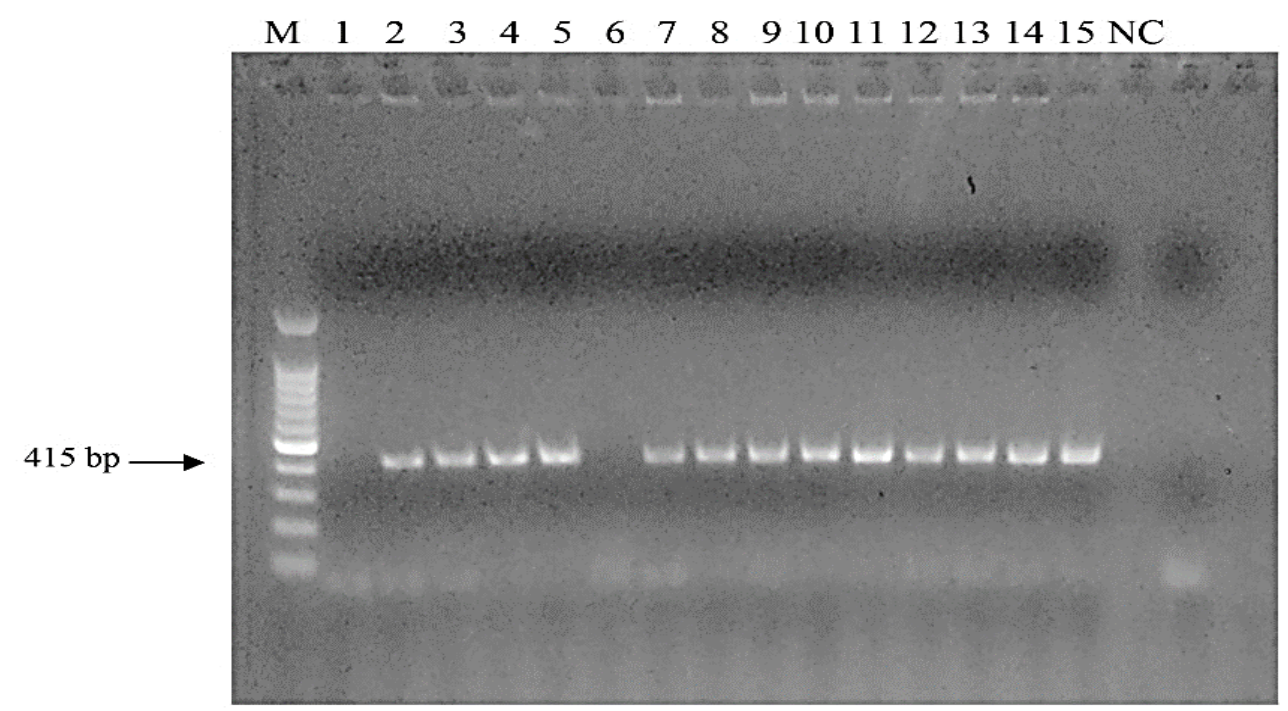

First lane, molecular weight marker; Gene Ruler 100 bp DNA ladder, lanes numbered 2, 3, 4, 5, 7, 8, 9, 10, 11, 12, 13, 14, 15 show 415 bp bands of PCR products while lanes number 1 and 6 shows negative result. NC: Negative control

Fig 3a: Gel electrophoresis of the PCR products of blactx-M gene 


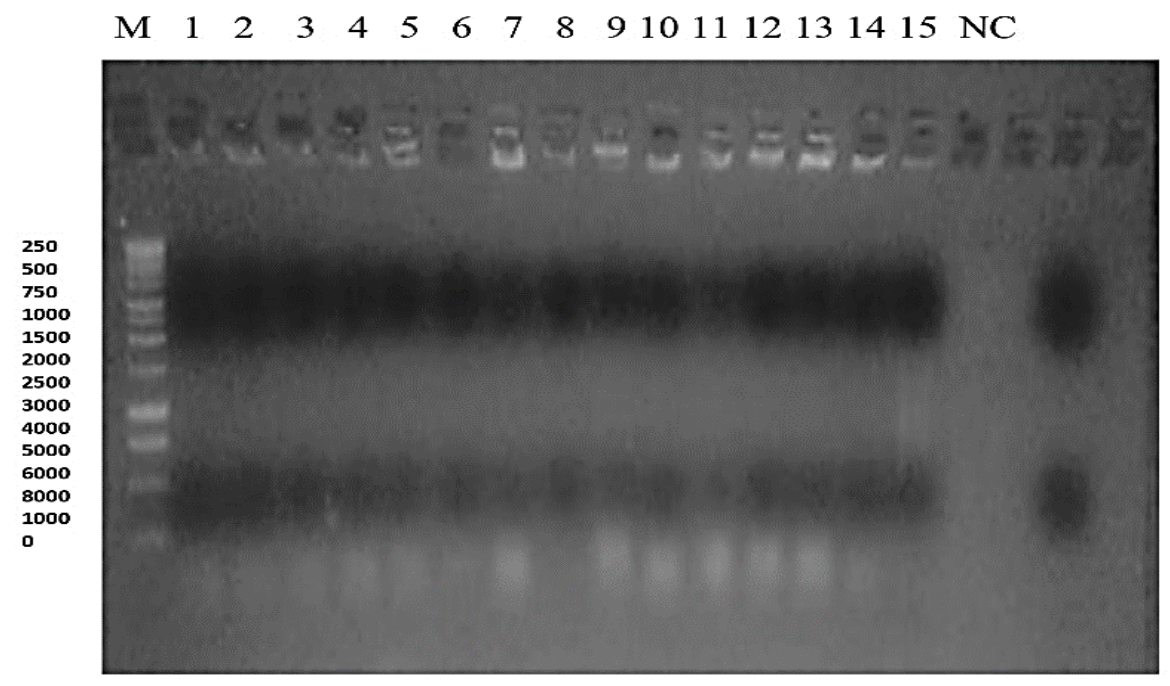
First lane, molecular weight marker; Gene Ruler 100 bp DNA ladder, lanes number 1 2, 3, 4, 5, 6, 7, 8, 9, 10, 11, 12, 13, 14, 15 shows negative

Fig 3b: Gel electrophoresis of the PCR products of blatem gene

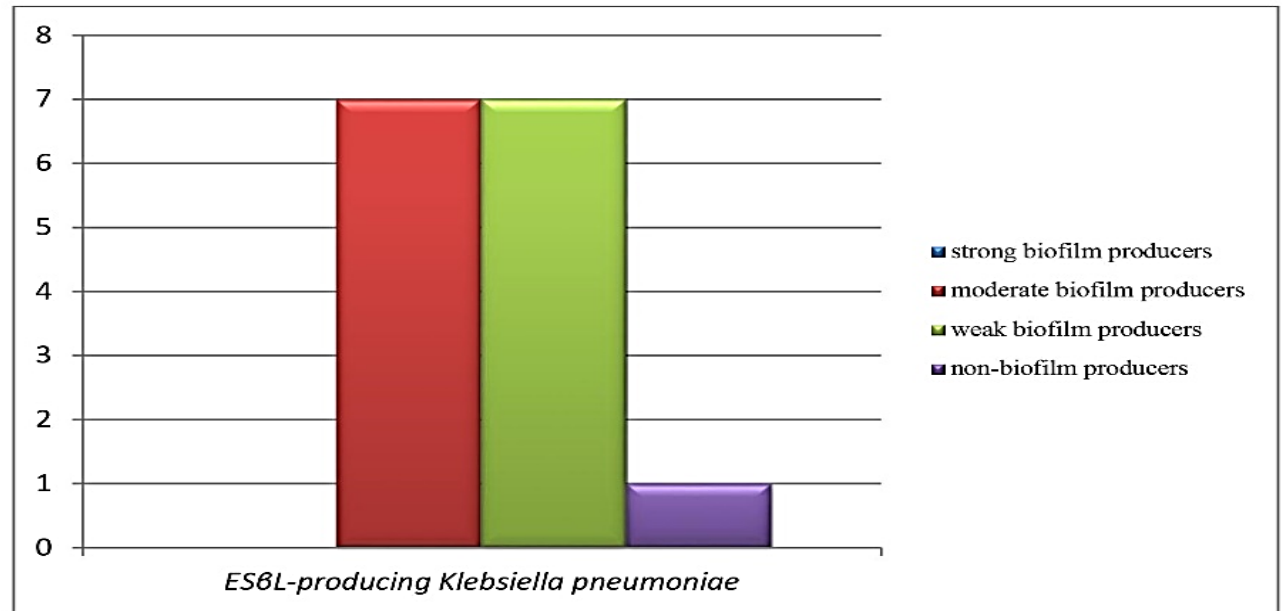

Fig 4: Detection of biofilm formation by the TCP method

\section{Discussion:}

During the study period, $K$. pneumoniae was involved in $6.3 \%$ of clinical infections among the 630 patients, a rate that is similar to that reported by Khalifa and Khedher (12). All the $K$. pneumoniae isolates were resistant to ampicillin and ticarcillin $(100 \%)$, which is consistent with the findings of Lagha et al., (24) and Muggeo et al., (25) in their previous studies. However, they were highly sensitive to amoxicillin/clavulanic acid (AMC) (90\%) and piperacillin/tazobactam $(97.5 \%)$, a finding that is also consistent with that of Rasamiravaka et al., (26) especially for AMC, although Muggeo et al., (25) and Khalifa and Khedher (12) reported $K$. pneumoniae isolates with intermediate resistance to $A M C$ in their studies, while higher AMC resistance rates were reported by Lagha et al., in 2014 (24) and Benaicha et al., in 2017 (27). However, for piperacillin/tazobactam combination, the resistance rate $(2.5 \%)$ in our study is lower than the rates reported by Lagha et al., (24) and Muggeo et al., (25). The decrease in the resistance rate may be an indicator of the presence of CTX-M type $\beta$-lactamases and the association of penicillinases with inhibitors, which permit recovery of the activity of the molecules. The $\beta$-lactamase inhibitors have structural similarity with penicillin, and are effective against many sensitive organisms expressing class A lactamases (17). In addition, the combination of penicillin and $\beta$ lactamase inhibitor has been actively used in the treatment of infections caused by ES $\beta$ Lproducing bacteria and could be proposed for outpatient treatment of urinary tract infections caused by ES $\beta$ L-producing Escherichia coli strains $(1,28)$.

All the $K$. pneumoniae isolates in the study were sensitive to cefoxitin, imipenem and ertapenem which agrees with the reports of Alibi et al., (20) and Lagha et al., (24), al- 
though different susceptibility rates have been reported in many other studies (11, $15,25,26,29)$. Currently, carbapenems are the only class of antimicrobials historically effective against KP-ES $\beta \mathrm{L}$ producing strains (13), however, it is essential to ensure the rational use of carbapenems because there are no new antibiotics in the pipeline available for use in the near future for the treatment of infections caused by ES $\beta$ L-producing Enterobacteriaceae (1). On the other hand, $K$. pneumoniae isolates in our study were highly sensitive to amikacin, ofloxacin and ciprofloxacin, and moderately sensitive to cephalothin, cefotaxime, ceftazidime, gentamicin, tobramycin, and nalidixic acid, which agrees with findings of some other studies $(15,17,24,27,29)$.

However, Muggeo et al., (25) and Rasamiravaka et al., (26) reported lower sensitivity $(83 \%)$ to amikacin in their studies compared to $97.5 \%$ in our own study. Only half of the $K$. pneumoniae isolates were sensitive to trimethoprim/sulfamethoxazole and nitrofurantoin. Rasamiravaka et al., (26) and Vuotto et al., (15) have reported differing susceptibility rates of $K$. pneumoniae isolates to trimethoprim/sulfamethoxazole in their studies. The fluoroquinolones (FQ) are the potential drug of choice for treating infections caused by $\beta$-lactamase-producing enterobacteria that are usually FQ sensitive (25). However, Muggeo et al., (25) reported 100\% resistance of $K$. pneumoniae ST395 to fluoroquinolones in north-eastern France, which is contrary to the findings of high susceptibility in our study. Klebsiella species are naturally sensitive to $F Q$, but the misuse of these antibiotic in human and veterinary medicine practices have, over the past decades, resulted in evolution of resistance to this antibiotic family, reduced their effectiveness, and compromised the future use of this important class of antibacterial drugs (12).

In our study, 15 of the $40(37.5 \%) \mathrm{K}$. pneumoniae isolates were ES $\beta$ L-producing strains, which is proximate to $41.1 \%$ rate reported by Pirzaman et al., (2). Different prevalence rates for ES $\beta$ L-producing strains have been reported in Tunisia (12), Algeria (24) and Russia (30), and ES $\beta$ L rates are usually higher in Asian countries, with up to $75 \%$ (17). The phenomenon of ESBL production has been observed in various pathogenic bacteria, but more frequent in $E$. coli and $K$. pneumoniae. The KP-ESBL strains were most frequently recovered from urine in our study which is consistent with the findings of other studies $(2,26,27,31,32,33)$, probably because urine is about the most commonly collected specimens for clinical investigation. Infections caused by ESBL-producing bacteria can occur in people of all ages, but distribution could be determined by the immunological status of patients and prevalence of antibiotic misuse. $\mathrm{KP}-\mathrm{ES} \beta \mathrm{L}$ isolates were recovered across all age groups in our study but most frequently in age group 21-30 years (20\%), although the number of isolates from patients in ours study are too few to make any significant inference. However, Lagha et al., (24) reported that the most KP-ES $\beta$ L were recovered from patients between the ages 27-85 years, Gravey et al., (34) reported 4.1\% KP-ESßL rate in the age group $18-64$ years and $4.2 \%$ in the age group $>65$ years. $K$. pneumoniae isolates as well as KP-ES $\beta \mathrm{L}$ strains were mostly recovered from male patients in our study. This is in close agreement with those of Bush et al., (33), Deng et al., (35) and Lagha et al., (24).

Also, most KP-ES $\beta L$ strains were isolated from the intensive care and general surgery units of the hospital, with $33.3 \%$ and $20 \%$ rates respectively. This agrees with the finding of Lagha et al., (24), but Khalifa and Khedher (12) reported lower rates than ours, with rates of $5 \%$ in paediatrics, $2.5 \%$ in medical resuscitation, and $0 \%$ in surgical unit. Numerous studies have reported isolation of KP-ES $\beta L$ strains from hospitalized patients and nosocomial epidemics caused by these strains have been reported mainly in intensive care units (20). We did not isolate KP$E S \beta L$ strain from infectious, oncology, pneumology, haematology and child surgery departments of the hospital. Although, this might suggest good infection prevention and control practices in these service departments, the limited KP-ESßL strains in this study cannot allow us to generalize this finding.

PCR assays detected group 1 blactx-M genes in most $(86.7 \%)$ of the KP-ES $\beta$ L producing isolates, while few (13.3\%) isolates did not carry the gene. This is similar to what Alibi et al., (20) reported in their study for bla $_{\text {СTX-M }}$ but in addition, they reported bla in $56.8 \%$ of their isolates. However, Paterson et al., (36) reported $23.3 \%$ bla bla TEM among their isolates. In Abidjan, Côte d'Ivoire, Guessennd et al., (31) reported that $63.4 \%$ of their strains carried bla TEM, $58.5 \%$ carried group 1 bla $_{\text {CTX-M, none carried groups }}$

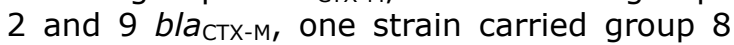
bla $a_{\text {CTX-M }}$ and three strains carried blaTEM, blasHv and group1 bla in Korea by Jung et al., (32), only group 1 bla СTX-M $(75.9 \%)$ and/or group 9 bla CTX-M $(20.5 \%)$ were reported. In an Egyptian study, blacтX-м was reported in three cases and blaTEM was detected only in one case (37). KP-ESßL strains carrying bla blaTEM genes are usually resistant to third generation cephalosporins (ceftriaxone, cefotaxime, ceftazidime), and several studies have shown that the presence of these genes could confer resistance to the third-generation cephalosporins (38). With the wide- 
spread use of cefotaxime and ceftriaxone (36), it is not surprising that bla $a_{\mathrm{CTX}-\mathrm{M}} \mathrm{ES} \beta \mathrm{L}$ strains are now found in many countries and reported at high rates among $K$. pneumoniae and other bacteria pathogens (20).

It has been widely reported in the literature that biofilm production provides a significant benefit by protecting pathogens against host immune system and reducing susceptibility to antibiotic therapy. In our study, $46.7 \%$ of KP-ES $\beta$ L strains were moderate and $46.7 \%$ were mild biofilm producers, which agrees with the finding of Seifi et al., (7). Martino et al., (39) reported $48.5 \%$ of $K$. pneumoniae strains to be strong biofilm producers; Vuotto et al., (15) reported $67.5 \%$ of strains to be potent, and $25 \%$ to be moderate biofilm producers, and Khodadadian et al., (11) reported $91.2 \%$ of their isolates to be biofilm producers. Surgers et al., (40) have reported a close relationship between several virulence factors and the ability to produce biofilm. The ability of $K$. pneumoniae strains to adhere and colonize inert surfaces may be a general feature of this species, as high incidence of effective adhesion of $K$. pneumoniae strains to glass and polypropylene surfaces in clinical and water distribution systems, have been observed (39).

\section{Conclusion:}

Infections caused by ES $\beta$ L-producing Gram-negative bacteria are increasing, particularly in immunocompromised patients and in high-risk units of hospitals. These infections are associated with higher costs of healthcare in Algeria and worldwide, as a result of prolonged hospitalization and the use of expensive drugs. The prevalence of $\mathrm{KP}-\mathrm{ES} \beta \mathrm{L}-$ producing strains reported in this study is a reflection of the level of infection prevention and control practices in our hospital.

Surveillance of these antibiotic resistant pathogens by detection of $\beta$-lactamases and molecular identification of prevalent ES $\beta L$ genes, as well as good knowledge of biofilms formation, will be essential for reliable epidemiological characterization of these pathogens, in order to prevent the risk of transmission, and implement antibiotic stewardship and appropriate infection control measures.

\section{Acknowledgements:}

The authors acknowledge the staff of Public Health Department, Federico II University, Naples, Italy and Laboratory of Microbiology at the Regional Military University Hospital Oran, Algeria, for their collaborations.

\section{References:}

1. El Bouamri, M. C., Arsalane, L., Kamouni, Y., Berraha, M., and Zouhair, S. Recent Evolution of the Epidemiological Profile of the Extended Spectrum Beta-Lactamase Producing Uropathogenic Enterobacteria in Marrakech, Morocco. Progrès en urologie. 2014; 24 (7): 451-455.

2. Pirzaman, A. N., and Mojtahedi, A. Investigation of antibiotic resistance and the presence of integron genes among ESBL producing Klebsiella isolates. Meta Gene. 2018; 19: 37-41.

3. Belmonte, O., Drouet, D., Alba, J., Moiton, M. P., and Kuli, B. Évolution de la résistance des entérobactéries aux antibiotiques sur l'île de la Réunion: émergence des bêta-lactamases à spectre élargi. Pathologie Biologie. 2010; 58(1): 18-24.

4. Markovska, R., Stoeva, T., Boyanova, L., et al. Dissemination of successful international clone ST15 and clonal complex 17 among Bulgarian CTX-M-15 producing $K$. pneumoniae isolates. Diagn Microbiol Infect Dis. 2017; 89 (4) : 310-313.

5. Akturk, H., Sutcu, M., Somer, A., et al. Carbapenem-resistant Klebsiella pneumoniae colonization in pediatric and neonatal intensive care units: risk factors for progression to infection. Braz J Infect Dis. 2016; 20 (2): 134140.

6. Cescutti, P., De Benedetto, G., and Rizzo, R. Structural Determination of the Polysaccharide Isolated from Biofilms Produced by a Clinical Strain of Klebsiella Pneumoniae. Carbohydrate Research. 2016; 430: 29-35.

7. Seifi, K., Kazemian, H., Heidari, H., et al. Evaluation of Biofilm Formation Among Klebsiella pneumoniae Isolates and Molecular Characterization by ERIC-PCR. Jundishapur J Microbiol. 2016; 9 (1): e30682.

8. Delatour, C., Chalvon, N., Prieur, N., and Mateu, P. A history of community-acquired hypervirulent Klebsiella pneumoniae severe sepsis. Anaesthesia Critical Care and Pain Medicine. 2018; 37 (3): 273-275

9. Huang, Y. T., Jiang, J. Y., Hsu, M. S., et al. The prevalence of rectal carriage of Klebsiella pneumoniae amongst diabetic patients and their clinical relevance in Taiwan: A five-year prospective study. J Microbiol Immunol Infect. 2018; 51 (4): 510-518.

10. Hauser, N., Tanner, E., Keuroghlian, M., and Koduri, L. A case of Klebsiella oxytoca endocarditis in an intravenous drug user. ID Cases. 2017; 9: 77-78.

11. Khodadadian, R., Rahdar, H. A., Javadi, A. Safari, M., and Khorshidi, A. Detection of VIM-1 and IMP-1 genes in Klebsiella pneumoniae and relationship with biofilm formation. Microbial Pathogenesis. 2018; 115: 25-30.

12. Ben Haj Khalifa, A., and Khedher, M. Epidemioological study of Klebsiella spp. uropathogenic strains producing extended-spectrum blactamase in a Tunisian university hospital. Pathologie Biologie. 2012; 60 (2): e1-e5

13. Panda, P. K., Jhon, N., and Sao, S. Antibiogram, ESBL production and carbapenemase detection of Klebsiella spp. in hospital-acquired infection. Apollo Medicine. 2016; 13 (3): 156-162. Barrios, H., Garza-Ramos, U., Mejia-Miranda, I., et al. ESBL-producing Escherichia coli and Klebsiella pneumoniae: The most prevalent clinical isolates obtained between 2005 and 2012 in Mexico. J Global Antimicrob Resist. 2017; 10: 243-246.

15. Vuotto, C., Longo, F., Pascolini, C., et al. Biofilm formation and antibiotic resistance in Klebsiella pneumoniae urinary strains. J Appl Microbiol. 2017; 123 (4): 1003-1018.

16. Clinical and Laboratory Standards Institute. Performance standards for Antimicrobial 
Susceptibility; Twenty-Fourth informational supplement, 2014 Philadelphia.

17. Abrar, S., Vajeeha, A., Ul-Ain, N., and Riaz, S. Distribution of CTX-M group I and group III $\beta$ lactamases produced by Escherichia coli and Klebsiella pneumoniae in Lahore, Pakistan. Microbial Pathogenesis. 2017; 103: 8-12.

18. Lytsy, B., Sandegren, L., Tano, E., et al. The first major extended-spectrum $\beta$-lactamase outbreak in Scandinavia was caused by clonal spread of a multiresistant Klebsiella pneumoniae producing CTX-M-15. APMIS. 2008; 116 (4): $302-308$.

19. Woodford, N., Fagan, E. J., and Ellington, M. J. Multiplex PCR for rapid detection of genes encoding CTX-M extended-spectrum $\beta$-lactamases. J Antimicrob Chemother. 2005; 57 (1): 154-155.

20. Alibi, S., Ferjani, A., and Boukadida, J. Molecular characterization of extended spectrum betalactamases produced by Klebsiella pneumoniae clinical strains from a Tunisian Hospital. Médecine et Maladies Infectieuses. 2015; 45(4): 139-143.

21. Dashti, A. A., Jadaon, M. M., Abdulsamad, A. M., Dashti H. M. Heat Treatment of Bacteria: A Simple Method of DNA Extraction for Molecular Techniques. Kuwait Medical Journal. 2009; 41 (2): 117-122.

22. Christensen, G. D., Simpson, W. A., Younger, J. J., Baddour, L. M., and Barrett, F. F. Adherence of Coagulase-Negative Staphylococci to Plastic Tissue Culture Plates: a Quantitative Model for the Adherence of Staphylococci to Medical Devices. J Clin Microbiol. 1985; 22 (6): 9961006.

23. Extremina, C. I., Fonseca, A. F., Granja, P. L., and Fonseca, A. P. Anti-adhesion and antiproliferative cellulose triacetate membrane for prevention of biomaterial-centred infections associated with Staphylococcus epidermidis. Int J Antimicrob Agents. 2010; 35 (2): 164-168.

24. Lagha, N., Abdelouahid, D. E., Hassaine, H., Robin, F., and Bonnet, R. First characterization of CTX-M-15 and DHA-1 $\beta$-lactamases among clinical isolates of Klebsiella pneumoniae in Laghouat Hospital, Algeria. Afri J Microbiol Res. 2014; 8 (11): 1221-1227.

25. Muggeo, A., Guillard, T., Klein, F., et al. Spread of Klebsiella pneumoniae ST395 non-susceptible to carbapenems and resistant to fluoroquinolones in North-Eastern France. J Global Antimicrob Resist. 2017; 13: 98-103.

26. Rasamiravaka, T., Shaista Sheila, H. S. L., Rakotomavojaona, T., Rakoto-Alson, A. O., and Rasamindrakotroka, A. Changing Profile and Increasing Antimicrobial Resistance of Uropathogenic Bacteria in Madagascar. Med Mal Infect. 2015; 45 (5): 173-176.

27. Benaicha, H., Barrijal, S., Ezzakkioui, F., and Elmalki, F. Prevalence of PMQR genes in E. coli and Klebsiella spp. isolated from North-West of Morocco. J Global Antimicrob Resist. 2017; 10: 321-325.

28. Rodriguez-Bano, J., Navarro, M. D., Retamar, P., Picon, E., and Pascual, A. $\beta$-Lactam/ $\beta$-Lactam Inhibitor Combinations for the Treatment of Bacteremia Due to Extended-Spectrum $\beta$ Lactamase-Producing Escherichia coli: A Post Hoc Analysis of Prospective Cohorts. Clin Infect Dis. $2012 ; 54$ (2): 167-174.
29. Singh, S. K., Mishra, M., Sahoo, M., et al. Antibiotic resistance determinants and clonal relationships among multidrug-resistant isolates of Klebsiella pneumoniae. Microbial Pathogenesis. 2017; 110: 31-36.

30. Edelstein, M., Pimkin, M., Palagin, I., Edelstein, I., and Stratchounski, L. Prevalence and Molecular Epidemiology of CTX-M ExtendedSpectrum $\beta$-Lactamase-Producing Escherichia coli and Klebsiella pneumoniae in Russian Hospitals. Antimicrob Agents Chemother. 2003; 47 (12): 3724-3732.

31. Guessennd, N., Bremont, S., Gbonon, V., et al. Résistance aux quinolones de type qnr chez les entérobactéries productrices de bêtalactamases à spectre élargi à Abidjan en Côte d'Ivoire. Pathologie Biologie. 2008; 56 (7-8): 439-446.

32. Jung, Y., Lee, S. S., Song, W., Kim, H. S., and Uh, Y. In vitro activity of flomoxef against extended spectrum $\beta$-lactamase producing Escherichia coli and Klebsiella pneumoniae in Korea. Diag Microbiol Infect Dis. 2018; 94 (1): 88-92.

33. Bush, K. R., Ellison, J., Hearn, K., Pfister, T., and Taylor, G. A comparison of extended-spectrum beta-lactamase (ESBL)-producing Escherichia coli and Klebsiella pneumoniae bloodstream infections in Alberta using a provincial surveillance system. Infect Contr Hosp Epidemiol. 2019; 1.

34. Gravey, F., Loggia, G., de La Blanchardière, A. and Cattoir, V. Bacterial epidemiology and antimicrobial resistance profiles of urinary specimens of the elderly. Médecine et Maladies Infectieuses. 2017; 47 (4): 271-278.

35. Deng, J., Li, Y. T., Shen, X., et al. Risk factors and molecular epidemiology of extendedspectrum $\quad \beta$-lactamase-producing Klebsiella pneumoniae in Xiamen, China. J Global Antimicrob Resist. 2017; 11: 23-27.

36. Paterson, D. L., Hujer, K. M., Hujer, A. M., et al. Extended-Spectrum $\beta$-Lactamases in Klebsiella pneumoniae Bloodstream Isolates from Seven Countries: Dominance and Widespread Prevalence of SHV- and CTX-M-Type $\beta$ Lactamases. Antimicrob Agents Chemother. 2003; 47 (11): 3554-3560.

37. Ahmed, O. I., El-Hady, S. A., Ahmed, M., and Ahmed, I. Z. Detection of bla SHV and bla CTX$M$ genes in ESBL producing Klebsiella pneumoniae isolated from Egyptian patients with suspected nosocomial infections. Egyptian Journal of Medical Human Genetics. 2013; 14 (3): 277-283.

38. Ahoyo, A. T., Baba-Moussa, L., Anagon, A. E., et al. Incidence d'infections liées à Escherichia coli producteur de bêta lactamase à spectre élargi au Centre hospitalier départemental du Zou et Collines au Bénin. Médecine et Maladies Infectieuses. 2007; 37 (11): 746-752.

39. Martino, P. D., Cafferini, N., Joly, B., and Darfeuille-Michaud, A. Klebsiella pneumoniae type pili facilitate adherence and biofilm formation on abiotic surfaces. Res Microbiol. 2003; 154: 9-16.

40. Surgers, L., Boyd A., Girard P. M., Arlet, G., and Decré, D. Biofilm formation by ESBL-producing strains of Escherichia coli and Klebsiella pneumoniae. Int J Med Microbiol. 2018; 309 (1): 13-18. 